\title{
Appraising the Current Condition of Business Entities in the Manufacturing Industry
}

\author{
Mamedova Zul'fiya Hasan \\ Assistant Professor, Azerbaijan State Oil and Industry University, Baku, Azerbaijan
}

\begin{abstract}
The paper emphasizes that entrepreneurship, owing to its widespread character, determines largely the socioeconomic and, in a way, the country's political development. It also considers the sources of entrepreneurship funding. Entrepreneurship in Azerbaijan as a whole is escalating and developing. On the other hand, all this took shape by applying the residual principle in supporting enterprises, and because of lack of a concrete and distinct government policy. The key problems were identified and the reforms being introduced were shown to have a positive effect on entrepreneurship. However, at the same time, in view of the immature condition of the reforms, development of entrepreneurship in the country, especially in the manufacturing industry, calls for substantial expenditures and is being retarded. Hence, coherent changes in the legislation, which would lay down a clear and stable framework for current activities, especially for business planning of business entities, would be a significant step.
\end{abstract}

Keywords: State, Entrepreneurship, Business Activities, Financing, Sources of Funding, Innovation

Over the past decades, the role and place of the manufacturing industry in the socioeconomic development of the country and its separate regions, and its siting has changed dramatically. Its share in the Gross National Product (GNP), national income and especially in the employment level has been dropping. This is especially typical for developed countries where the employment level in the manufacturing industry is declining because the services sector is expanding. The decline is occurring mainly in industries with obsolete equipment and outdated technologies. The number of employed in industries with low wages has been reducing partially because such industries are being moved to developing countries. One can distinguish three groups of countries with a different pattern of development of the manufacturing industry and its specific siting trends. The first group includes developed capitalist countries; the second group, different third-world countries, which are very dissimilar in their level of development; the third group, countries with a transition economy (East European countries, states formed on the territory of the former USSR, and former socialist countries in Asia that account for two-thirds of the area and $45 \%$ of Eurasia's population). The balance between these three groups has been changing dramatically. Countries in South-Eastern Asia and China have become the major drivers of global industrialisation, with a significant effect on the balance of forces in the global economy. The structure of the manufacturing industry in the world is changing continuously. This affects the geographical siting of production. As a rule, the share of industries playing a key role in technological progress (chemistry, radio electronics, instrument building and other research-intensive industries) has been growing in developed countries. At the same time, the share of legacy industries (food processing, metallurgy, consumer goods, etc.) is declining.

A characteristic feature of current manufacturing industry siting is that its enterprises are being built outside the limits of major urban conglomerations. This diminishes the relative role of major urban conglomerations with a high share of such an industry. In industrially developed countries, primarily those with a small area, where the territorial production structure has taken shape, and almost the entire product growth has been achieved by increasing labor productivity, the shifts in manufacturing industry siting are not so evident. In developed countries with big territories, the territorial changes in industry siting are more significant. In the first place, they are pronounced in places where development of industry is underway in new, often hard-to-access regions (Alaska in the U.S.A., northern and western regions in Canada, and others). In all these cases, rich mineral resources are the driving factor in the territorial shifts of production. The manufacturing industry follows the mining industry into these regions. Development of new kinds of transport and associated transportation cost reduction have weakened raw material dependence. This has isolated the manufacturing industry territorially from fuel and raw materials bases. As a result, countries with small own fuel and raw materials resources (Japan, Italy and others) have managed to develop a major modern manufacturing industry because the problem of supplying resources has lost its significance. At the same time, the significance of transport capabilities and of the geographical location has increased. This made the manufacturing industry move closer to the sea. Along with a focus on lowcost labour, this factor facilitated the growth of the manufacturing industry in "new industrialisation countries".

On the other hand, the manufacturing industry has an adverse effect on environmental contamination and increases the ecological interdependence of countries. Its following branches have the most drastic effect on the natural environment: 


\section{International Advanced Research Journal in Science, Engineering and Technology}

Vol. 6, Issue 5, May 2019

petroleum refining, metallurgy, the chemical industry, production of cement and industrial rubber articles, the pulp and paper industry, and some food processing industry branches. Since developed countries have the highest industrialisation and urbanisation indicators, they are the ones with the most substantial impact on the environment, and face the most severe ecological problems. Therefore, the introduction of resources and energy-saving technologies in the manufacturing industry has become in Azerbaijan one of the priority lines in the environmental conservation policy. The ecological factor in siting has been coming to the forefront with a steadily growing impact on industry siting.

In present-day Azerbaijan, the petroleum sector is playing a leading role in the fast-paced economic development in recent years. On the other hand, the non-petroleum sector has been recently moving gradually to the forefront. The petroleum sector, linked mainly to construction and trade, has grown recently by over 2.2 times.

As any other country that has survived the transition period, Azerbaijan has also staked on its natural resources to build a strong economy. As a whole, the manufacturing industry is one of the priority industries in the non-petroleum sector. Presently, in the manufacturing industry, the production of electric machines and equipment, spare parts, chemical products, building materials, ready-made textile products and other goods holds a prominent place. Business entities are an important factor in the export and production of manufactured products in Azerbaijan. They are those who manufacture export products in the market economy. At the same time, incentives and major advanced processing industrial complexes are required to manufacture such products. However, no incentives for developing such complexes exist at this point. This calls for improving the business environment, and increasing the volume of foreign and local investments in the non-petroleum sector. In this case, we do not mean the entire non-petroleum sector in Azerbaijan, comprising mostly retail trade, construction and transport, but rather the manufacturing sector. On the other hand, a crucial problem for entrepreneurs intending to export their own products is that they face tricky and time-consuming export-import procedures. This means that for each operation the entrepreneurs must collect many documents and undergo an involved process, with administrative obstacles existing at the same time.

A major obstacle also is that the tariffs for raw materials and semi-finished products imported to Azerbaijan exceed those for processed products by a factor of two. Thus, the majority of entrepreneurs shift to retail trade and construction because it is more profitable to import finished products. On the other hand, any raw materials need logistics centres and an appropriate infrastructure, which is also underdeveloped. All this makes the entrepreneurs import ready-to-use raw materials that can be stored without big costs. At the same time, this also degrades the incentives of foreign trade entrepreneurs, whereas the manufacturing industry is an activity demanding export/import operations.

As regards its main characteristic, the manufacturing industry can be classified into two major activity areas: processing agricultural raw materials, or the agribusiness complex, and processing extracted raw materials - industrial manufacturing.

The agribusiness complex, or $\mathrm{ABC}$, is a complex of economy branches taking part in growing agricultural stock, processing it and delivering finished products to the customer. The significance of the agribusiness complex is in supplying the country with foodstuffs and other consumer goods. The most common model of the agribusiness complex usually includes three sectors.

The first sector includes industries that manufacture means of production for agriculture and industries that process agricultural stock: tractor and agricultural machine building, manufacturing equipment for husbandry, and the food processing and consumer goods industry, production of mineral fertilisers, the formula feed and microbiological industry, and rural industrial facilities construction.

The second sector - agriculture proper (crop and livestock farming).

The third sector - system of industries for industrial processing and sale of agricultural stock and foodstuffs: the food processing industry, the consumer goods industry, the procurement system, transportation, storage and sale of ABC products.

The siting of the first and second branches of the agribusiness complex is defined largely by the territorial organisation of agricultural production. Processing, stocking and storage of agricultural products are focused largely to the consumer. The territorial concentration of the cultivation of potatoes, vegetables and other plant products in suburban and high-urbanised areas is also the result of development of homesteading and farming.

The geographical transportation location factor has gained significance virtually at the same time. This factor shifted the manufacturing industry closer to the sea. With a focus on low labour cost, this factor facilitated the growth of the manufacturing industry in "new industrialisation countries". However, the manufacturing industry has an adverse effect 


\section{International Advanced Research Journal in Science, Engineering and Technology}

Vol. 6, Issue 5, May 2019

on the environment, contaminates it, and the ecological mutual dependence of countries grows. Its following manufacturing branches have the most adverse effect on the environment: petroleum refining, the chemical industry, metallurgy, the pulp and paper industry, and the cement and industrial rubber articles industries.

Azerbaijan's strategy for development of the manufacturing industry builds on expanding the activities of industrial parks. If we speak about the key indices of the manufacturing industry, note that 154 state enterprises are engaged in this sector. Along with them, more than 12,000 physical persons-entrepreneurs are involved in the manufacturing sector, with the volume of work performed in this sector exceeding 7.2 bin manats. The annual average growth of the sector is 5-6\%. The average share of the manufacturing sector in the country's industrial production is $15-16 \%$, and in the non-state sector, $15 \%$. The average wage of workers in the manufacturing sector (over 100,000 workers) is 421 manats. But, concurrently with the government's focus on the development strategy and on building industrial parks, the private sector has been intensively building its own ones. Presently, only two such parks are in operation. One of them is the textile park of the Gilan Company, operating since 2012. This company has built a textile park, which fulfils practically the entire state order for textile products for the army, the state boundary service, the Ministry of Emergencies, the customs office, and the tax and education ministries. Another industrial park is linked to the Azersun Company that produces butter and other foodstuffs. As a whole, if we speak of enterprises and entrepreneurship entities in the manufacturing sector, the figures are as follows.

If we look at the number of enterprises, $71 \%$ of them are concentrated in the manufacturing sector. Their distribution is as follows (Table 1).

Table 1. Number of enterprises in the manufacturing sector

\begin{tabular}{|l|c|c|c|}
\hline \multicolumn{1}{|c|}{ Years } & 2013 & 2014 & 2015 \\
Indicators & & & \\
\hline Total number of enterprises & 2,527 & 2,534 & 2,588 \\
\hline In manufacturing & 1,764 & 1,762 & 1,771 \\
\hline Major and medium-size enterprises & 376 & 450 & 814 \\
\hline Small enterprises & 1,388 & 1,312 & 964 \\
\hline
\end{tabular}

Hence, the majority of enterprises in the manufacturing sector are involved in processing agricultural products to some extent. These are both food processing enterprises and those in the consumer goods industry sector.

However, if during the early years of independence the manufacturing industry was the leading player in the economy and accounted for up to $89.75 \%$ of the industry, its present share is small. At the same time, this sector is witnessing positive trends. If earlier in the 1990s and early 2000s its share was on the downward trend, the current one has reversed its pattern. In spite of the industrial production downturn, the manufacturing sector has been showing sustainable growth. According to official data, in 2013, 2014 and 2015 the manufacturing industry's product output was 6.4, 7 and 7.2 mln manats, respectively, and its share was $18.2 \%, 20.3 \%$ and $21.3 \%$.

Presently, Azerbaijan's economic development is demonstrating positive trends. In particular, industry output and investment activities are growing, and the competitiveness of certain manufacturing industry sectors has improved. However, drastic changes are needed in the structure of industry. Presently, diverse variations have been registered among different manufacturing industry sectors. If the food processing industry output has been gradually stabilising at 2.5 bin manats, either zero growth or a small one is evident in the tobacco and clothing industry, and as a whole in some other sectors of the consumer products industry. However, presently, metallurgy and the machine and equipment manufacturing industries are on the biggest downturn.

As a whole, analysis of structural transformations in this sector has shown that different industries have been adapting to business market conditions on a different scale. The best adaptation potentialities as per the product demand indicator belonged to the following industries: the fuel and energy complex, metallurgy, and the food processing industry. The share in the industry structure in 1990 was as follows: the fuel and energy complex, $16.1 \%$; metallurgy, 3.9\%; chemistry and petro chemistry, 6.5\%; machine building and metal working, $18.1 \%$; consumer products industry, 19.8\%; the food processing industry, 27.1\%; The indicators for 1995: the fuel and energy complex, 65.4\%; metallurgy, 1.1\%; chemistry and petro chemistry, 5.4\%; machine building and metal working, 3.6\%; the consumer products industry, $9.5 \%$; the food processing industry, $10.0 \%$. The indicators for 2014: the fuel and energy complex, $90.9 \%$; metallurgy, $1.9 \%$; chemistry and petro chemistry, $1.2 \%$; machine building and metal working, $1.3 \%$; the consumer products industry, $0.4 \%$; the food processing industry, $2.5 \%$. The products of these industries were in biggest demand in the domestic and foreign markets; hence, their share in the structure of industry increased. The enterprises of the machine building and the consumer products industries turned out to be the least adapted to market transformations. 


\section{International Advanced Research Journal in Science, Engineering and Technology}

Vol. 6, Issue 5, May 2019

The development of the manufacturing industry is the underpinning of the country's economic development. This sector is growing and developing owing to many driving factors. These factors are increasing production effectiveness and growth of competitiveness of manufactured products in the foreign and domestic markets. Experience of foreign countries shows that these problems should be tackled by using the strategy of industry development depending on the specific economic features of the country. One such strategy is exploiting natural resources with the attraction of foreign investments. The essence of this strategy is the development and export of natural resources with attraction of foreign investments. Another strategy is using low-cost labour for assimilating the production of competitive products and driving imported products from the market by offering lower prices. Yet another strategy is to draw on technological expertise, manufacture new goods and create demand for them. In the development of industry, special emphasis should be placed on its competitiveness. It plays the role of a production rate and output regulator, induces the producer to introduce advanced technologies, and increase labour productivity and develop technology. Thus, competition facilitates the removal of an ineffective enterprise from production, and it is a driving actor in the adjustment of prices. On the other hand, the number and role of small enterprises plays a major role in the development of an industry sector. A low level of investments is one of the crucial factors impeding the development of the manufacturing sector.

For many years, the government has reserved the right to provide guarantees for key investments in industries that would be financed by commercial banks and private investors. However, some sectors lately have been seeing positive trends. These are those linked in a way to extraction and refining of oil or to executing government orders. However, with insufficient investments, the positive effects of such activities can be much lower than expected ones or they can vanish entirely. Therefore, it is necessary to facilitate the creation of an open competitive environment and of conditions favourable for attracting investments to facilitate the rate of starting new enterprises in all sectors.

An indicator of a low level of investments in the manufacturing sector is that this sector relies essentially only on Azerbaijani capital with a 99.9\% share of all investments, whereas the share of foreign capital is only 0.1-0.2 mln manats, by the results of 2011-2013. On the other hand, the activities of the National Fund for Supporting Entrepreneurship (NFSE) can have a beneficial effect without government intervention on the development of entrepreneurship in the manufacturing sector. Note, however, that a substantial volume of concessional resources of the NFSE with the Ministry of Economics and Industry are marshalled directly to entrepreneurs in the agrarian sector. Thus, NFSE, through authorised credit organisations, issued $249 \mathrm{mln}$ manats of concessional loans to Azerbaijan entrepreneurs since early 2013. The loans are earmarked for implementing projects in the production of bread, livestock growing, weaving businesses, manufacture of construction materials, vegetable farming, and other sectors. Therefore, this sector presently calls for substantial investments.

\section{REFERENCES}

[1]. Batychko V.T. Entrepreneurship law. Compendium of lectures. Taganrog, TTI YuFU, 2011.

[2]. Berenov A.N. The raw materials development model: basic analytical approaches // Russian Entrepreneurship. 2012, (219). pp. 11-16.

[3]. Blaug M. Economic Theory in Retrospect. Moscow, 1994. 427 pp. [In Russian].

[4]. Blinov A.O. Small entrepreneurship. Organisational and legal aspects of activity. 2nd ed. M. Os'-89 Publishers, 1998.

[5]. Big Economics Dictionary. M. Institute of Economics, 1994.

[6]. Goldstein G.Ya. Fundamentals of Management. Study guide, 2nd ed. Published by TRTU, Taganrog, 2003.

[7]. Goncharenko L.P. Innovation Policy: Textbook. M. KNORUS, 2009.

[8]. Gorfinkel V.Ya., Shvandar V.A. A course in entrepreneurship. Moscow, YuNITI, 1997.

[9]. Civil Code of the Azerbaijan Republic.

[10]. Drucker P. Effective Management. Economic Tasks and Optimal Decisions. M. Fair-Press, 1998. 288 pp. [In Russian],

[11]. Dumnova N.A. State support of small entrepreneurship in the innovation field: Materials of the International Workshop "Innovation Strategy for Modernising Economic Systems". Orel, GIET, 2007.

[12]. Law of the Azerbaijan Republic "On Entrepreneurship".

[13]. Research in the specifics of entrepreneurship in Azerbaijan. Review of the goods and services market in Azerbaijan. Perm Chamber of Commerce and Industry. Perm, 2014.

[14]. Liutyi I.A., Kuliev R.A. Investment activities. Baku, 2009.

[15]. McConnell C.R., Brue S.L. Economics. Moscow, 2000 [In Russian],

[16]. Naumov V.N. Organisation of entrepreneurship. St. Petersburg, Piter Publishers, 2010.

[17]. Organisation of Entrepreneurship (Ed. Prof. A.S. Pelikh). M., MarT Publishers, 2003.

[18]. Fundamentals of Entrepreneurship. Ed. Yu.M. Osipova, Moscow, 2000.

[19]. Industry of Azerbaijan. Statistical Yearbook. Baku, TsSU, 2009, 580 pp. and 2011, 280 pp.

[20]. Stanlake J.F. Economics for Beginners. Moscow, 2004 [In Russian],

[21]. Customs Code of the Azerbaijan Republic. 